\title{
KERNFORSCHUNGSZENTRUM
}

\author{
KARLSRUHE
}

Juli 1968

Institut für Material- und Festkörperforschung

Irradiation Effects on the Mechanical Properties of Vanadium-Base Alloys

H. Böhm, W. Dienst, H. Hauck, H. J. Laue

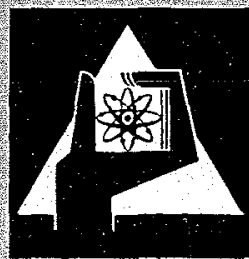

GESELLSCHAFT FUR KERNFORSCHUNG M.B.H. KARISRUHE 

H. Bohm, W. Dienst, H. Hauck, and H. J. Lave

\section{Irradiation Effects \\ on the Mechanical Properties of Vanadium-Base Alloys}

Authorized Reprint from the Copyrighted Effects of Radiation on Structural Metals Special Technical Publication No. 426 



\section{Irradiation Effects on the Mechanical Properties of Vanadium-Base Alloys}

REFERENCE: H. Böhm, W. Dienst, H. Hauck, and H. J. Laue, "Irradiation Effects on the Mechanical Properties of Vanadium-Base Alloys," Effects of Radiation on Structural Metals, ASTM STP 426, Am. Soc. Testing Mats., 1967, pp. 95-106.

ABSTRACT: Irradiation experiments were carried-out-on 14-different vanadium-base alloys. After irradiation $\left(1.4 \times 10^{\text {i1 }}\right.$ neutrons $/ \mathrm{cm}^{2}>100$ $\mathrm{kev}$ ) the specimens were tested in a tension test between room temperature and $750 \mathrm{C}$.

In the binary vanadium-titanium alloys the increase in yield strength at room temperature is independent of the titanium content. The temperature at which a complete recovery from radiation damage can be observed is influenced by the titanium content.

At 650 and $750 \mathrm{C}$ none of the vanadium alloys showed signs of radiation-induced, high-temperature embrittlement.

KEY WORDS: radiation effects, neutron radiation, tension test, vanadium alloys, high temperature, titanium alloys, yield strength, embrittlement, fracture

In the light of existing knowledge, vanadium alloys exhibit favorable neutron physics properties for fast reactors along with high strength at elevated temperatures. This behavior together with sufficient corrosion resistance in sodium at temperatures of about $650 \mathrm{C}$ makes vanadium alloys appear to be suitable canning materials for a sodium-cooled fast breeder $[1,2] .^{2}$

No information is yet available about the change in mechanical properties by neutron irradiation. In this paper we shall report on investigations which were carried out to determine the influence of neutron irradiation on the mechanical properties.

\section{Experimental Procedures}

The investigation was carried out on the following alloys (composition by weight per cent):

1. V-3Ti

\footnotetext{
${ }^{1}$ Kernforschungszentrum, Karlsruhe, Germany.

${ }^{2}$ The italic numbers in brackets refer to the list of references appended to this paper.
} 
TABLE 1-Infuence of irradiation on the mechanical properties of vahadium-base alloys.

\begin{tabular}{|c|c|c|c|c|c|c|c|c|c|c|c|c|c|c|c|c|}
\hline \multirow[b]{2}{*}{ Alloy } & & \multicolumn{3}{|c|}{$20 \mathrm{C}$} & \multicolumn{3}{|c|}{$200 \mid \mathrm{C}$} & \multicolumn{2}{|r|}{$400 \mathrm{C}$} & & \multicolumn{3}{|c|}{$650 \mathrm{C}$} & \multicolumn{3}{|c|}{$750 \mathrm{C}$} \\
\hline & & 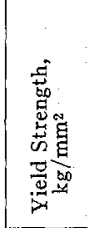 & 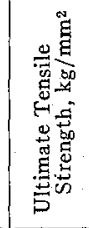 & $\begin{array}{l}50 \\
10\end{array}$ & 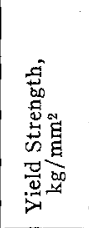 & 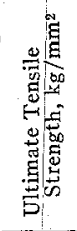 & 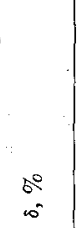 & 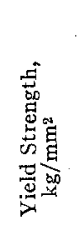 & 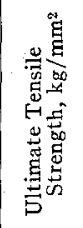 & $\therefore$ & 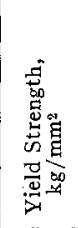 & 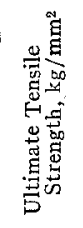 & $5^{\circ}$ & 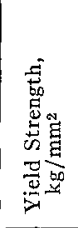 & 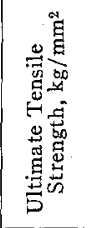 & $\begin{array}{l}50 \\
0^{\circ}\end{array}$ \\
\hline V-3Ti. & $\begin{array}{l}\text { unirradiated } \\
\text { irradiated }\end{array}$ & $\begin{array}{l}44.5 \\
76.4\end{array}$ & $\begin{array}{l}56.1 \\
76.7\end{array}$ & $\begin{array}{r}17.1 \\
1.5\end{array}$ & $\ldots$ & $\therefore$ & $\ldots$ & & $\ldots$ & $\ldots$ & $\begin{array}{l}33.2 \\
38.5\end{array}$ & $\begin{array}{l}45.2 \\
45.6\end{array}$ & $\begin{array}{r}10.5 \\
8.2 \\
\end{array}$ & $\ldots$ & $\ldots$ & $\ldots$ \\
\hline V-5Ti. . & $\begin{array}{l}\text { unirradiated } \\
\text { irradiated }\end{array}$ & $\begin{array}{l}42.4 \\
76.7\end{array}$ & $\begin{array}{l}52.7 \\
76.7\end{array}$ & $\left|\begin{array}{r}17.1 \\
1.5\end{array}\right|$ & & . & & & & $\ldots$ & $\begin{array}{l}30.3 \\
36.8\end{array}$ & $\begin{array}{l}46.0 \\
45.6\end{array}$ & $\begin{array}{r}10.5 \\
8.4\end{array}$ & $\ldots$ & $\ldots$ & $\ldots$ \\
\hline V-10Ti. & $\begin{array}{l}\text { unirradiated } \\
\text { irradiated }\end{array}$ & $\begin{array}{l}47.7 \\
87.7\end{array}$ & $\begin{array}{l}57.3 \\
87.7\end{array}$ & $\begin{array}{r}21.1 \\
1.5\end{array}$ & $\ldots$ &. & $\ldots$ & $\ldots$ & $\ldots$ & $\ldots$ & $\begin{array}{l}32.5 \\
32.2\end{array}$ & $\begin{array}{l}51.2 \\
51.9\end{array}$ & $\begin{array}{l}13.3 \\
13.8\end{array}$ & $\ldots$ & $\ldots$ & $\ldots$ \\
\hline V-20Ti.. & $\begin{array}{l}\text { unirradiated } \\
\text { irradiated }\end{array}$ & $\begin{array}{l}65.5 \\
94.5\end{array}$ & $\begin{array}{l}72.3 \\
94.5\end{array}$ & \begin{tabular}{|r|}
18.4 \\
1.8
\end{tabular} & & . & & & & $\ldots$ & $\begin{array}{l}40.1 \\
39.3\end{array}$ & $\begin{array}{l}56.8 \\
55.8\end{array}$ & $\begin{array}{l}15.7 \\
15.8\end{array}$ & $\ldots$ & $\ldots$ & $\ldots$ \\
\hline $\mathrm{V}-5 \mathrm{Ti}-20 \mathrm{Cb}$ & $\begin{array}{l}\text { unirradiated } \\
\text { irradiated }\end{array}$ & $\begin{array}{r}65.1 \\
115.7\end{array}$ & $\begin{array}{r}73.7 \\
116.0\end{array}$ & $\begin{array}{r}20.5 \\
1.4\end{array}$ & & .. & . & $\ldots$ & $\ldots$ & $\ldots$ & $\begin{array}{l}48.8 \\
53.6\end{array}$ & $\begin{array}{l}72.2 \\
71.1\end{array}$ & $\begin{array}{l}15.3 \\
12.8\end{array}$ & $\ldots$ & $\ldots$ & $\ldots$ \\
\hline $\mathrm{V}-10 \mathrm{Ti}-20 \mathrm{Cb}$ & $\begin{array}{l}\text { unirradiated } \\
\text { irradiated }\end{array}$ & $\begin{array}{r}74.8 \\
115.5\end{array}$ & $\begin{array}{r}82.5 \\
116.4\end{array}$ & $\begin{array}{r}20.4 \\
2.5\end{array}$ & & $\because$ & & & & . & $\begin{array}{l}47.5 \\
48.7\end{array}$ & $\begin{array}{l}68.0 \\
64.5\end{array}$ & $\begin{array}{l}13.5 \\
14.5\end{array}$ & & & $\ldots$ \\
\hline $\mathrm{V}-20 \mathrm{Ti}-20 \mathrm{Cb}$ & $\begin{array}{l}\text { unirradiated } \\
\text { irradiated }\end{array}$ & $\begin{array}{r}82.6 \\
114.2\end{array}$ & $\begin{array}{r}87.8 \\
115.5\end{array}$ & $\begin{array}{r}17.1 \\
2.4\end{array}$ & $\ldots$ & $\ldots$ & 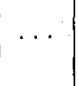 & & 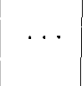 & $\ldots$ & $\begin{array}{l}50.8 \\
53.4\end{array}$ & $\begin{array}{l}68.0 \\
66.7\end{array}$ & $\begin{array}{l}13.7 \\
11.7\end{array}$ & $\ldots$ & $\ldots$ & $\ldots$ \\
\hline V-10Ti-2Cr. & $\begin{array}{l}\text { unirradiated } \\
\text { irradiated }\end{array}$ & $\begin{array}{l}47.3 \\
86.2\end{array}$ & $\begin{array}{l}56.0 \\
87.3\end{array}$ & $\begin{array}{r}19.8 \\
1.5\end{array}$ & $\begin{array}{l}40.2 \\
74.0\end{array}$ & $\begin{array}{l}49.8 \\
75.0\end{array}$ & $\begin{array}{r}16.3 \\
1.8\end{array}$ & $\begin{array}{l}37.8 \\
63.0\end{array}$ & $\begin{array}{l}48.9 \\
64.6\end{array}$ & $\begin{array}{r}11.2 \\
2.0\end{array}$ & $\begin{array}{l}30.4 \\
34.2\end{array}$ & $\begin{array}{l}50.8 \\
54.9\end{array}$ & $\begin{array}{l}17.8 \\
15.8\end{array}$ & $\begin{array}{l}27.2 \\
28.0\end{array}$ & $\begin{array}{l}45.2 \\
47.0\end{array}$ & $\begin{array}{l}16.8 \\
16.0\end{array}$ \\
\hline
\end{tabular}




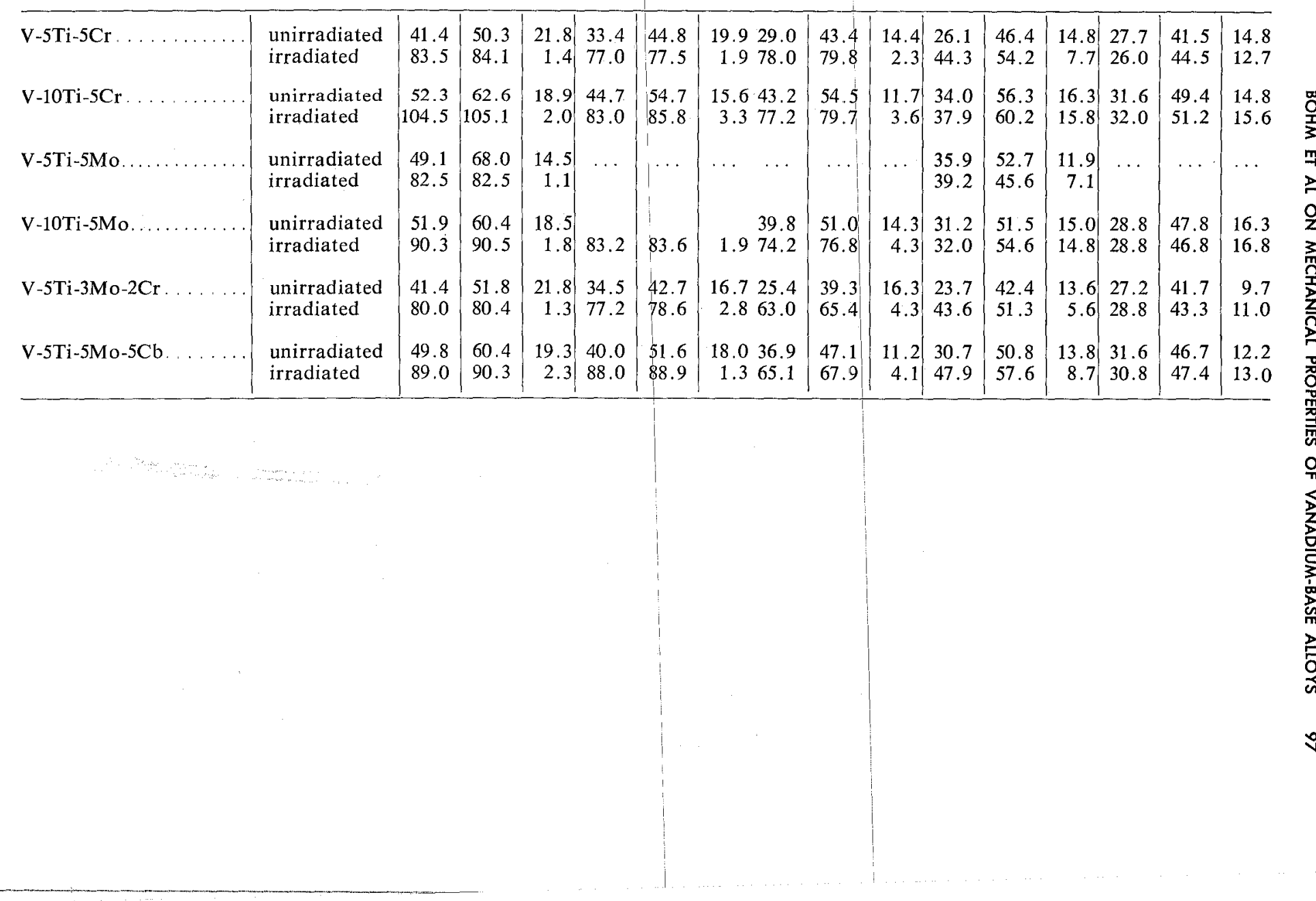



2. $\mathrm{V}-5 \mathrm{Ti}$
3. $\mathrm{V}-10 \mathrm{Ti}$
4. V-20Ti
5. $\mathrm{V}-5 \mathrm{Ti}-20 \mathrm{Cb}$
6. $\mathrm{V}-10 \mathrm{Ti}-20 \mathrm{Cb}$
7. $\mathrm{V}-20 \mathrm{Ti}-20 \mathrm{Cb}$
8. V-5Ti-5Mo
9. $\mathrm{V}-10 \mathrm{Ti}-2 \mathrm{Cr}$
10. V-10Ti-5Mo
11. V-5Ti-5Cr
12. $\mathrm{V}-10 \mathrm{Ti}-5 \mathrm{Cr}$
13. $\mathrm{V}-5 \mathrm{Ti}-3 \mathrm{Mo}-2 \mathrm{Cr}$
14. V-5 Ti-5Mo-5Cb
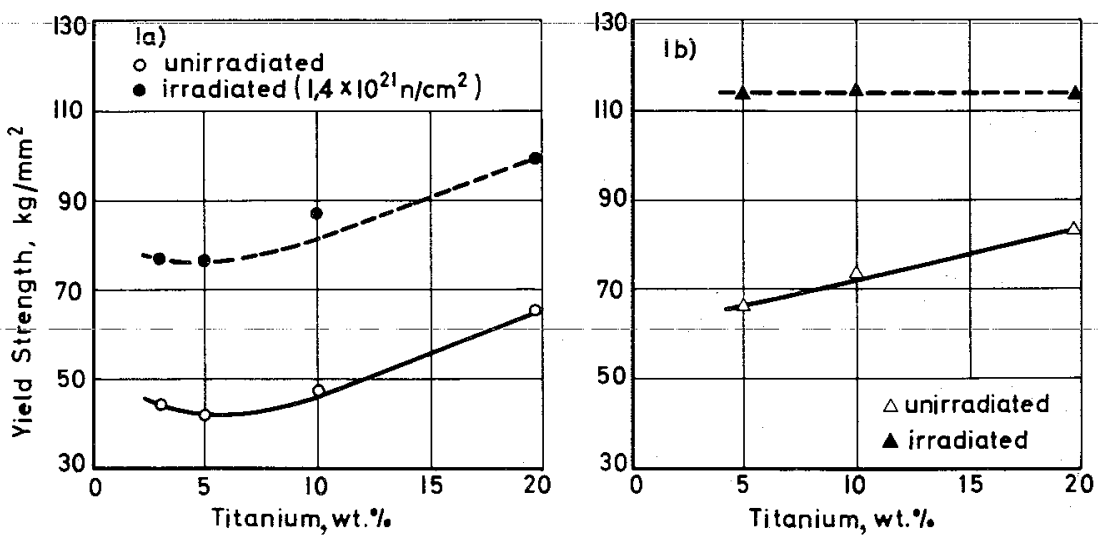

(a) V-Ti-alloys

(b) $\mathrm{V}-20 \mathrm{Cb}-\mathrm{Ti}$ alloys

FIG. 1-Pre- and postirradiation yield strength of vanadium alloys at room temperature.

The content of the interstitial impurities, determined in some alloys, is in the range of 1000-ppm oxygen, 700-ppm carbon, and 450-ppm nitrogen.

The alloys were fabricated by arc melting by Metallgesellschaft AG, swaged to rods of $5 \mathrm{~mm}$ diameter and then were vacuum-annealed for $1 \mathrm{hr}$ at $900 \mathrm{C}$.

Five specimens of each alloy were irradiated in the BR2-reactor at Mol, Belgium. The specimens of the Alloys 1-8, irradiated in a first irradiation test, were in direct contact with the cooling water of the reactor, whereas the specimens of the Alloys 9-14 were encapsulated in aluminum capsules filled with helium. The irradiation temperature in the first experiment was about $50 \mathrm{C}$, in the second experiment about $100 \mathrm{C}$. 
The average integrated thermal flux was $1.2 \times 10^{21}$ neutrons $(\mathrm{n}) / \mathrm{cm}^{2}$; the average fast flux $(>100 \mathrm{kev})$ was $1.4 \times 10^{21} \mathrm{n} / \mathrm{cm}^{2}$.

Afterwards, the mechanical properties were determined in a tension tests at room temperature, $200,400,650$, and $750 \mathrm{C}$ with a deformation rate of $0.2 / \mathrm{min}$. For investigation of the recovery process of the mechanical properties, specimens of some alloys were vacuum-annealed at $600 \mathrm{C}$ for $5 \mathrm{hr}$.

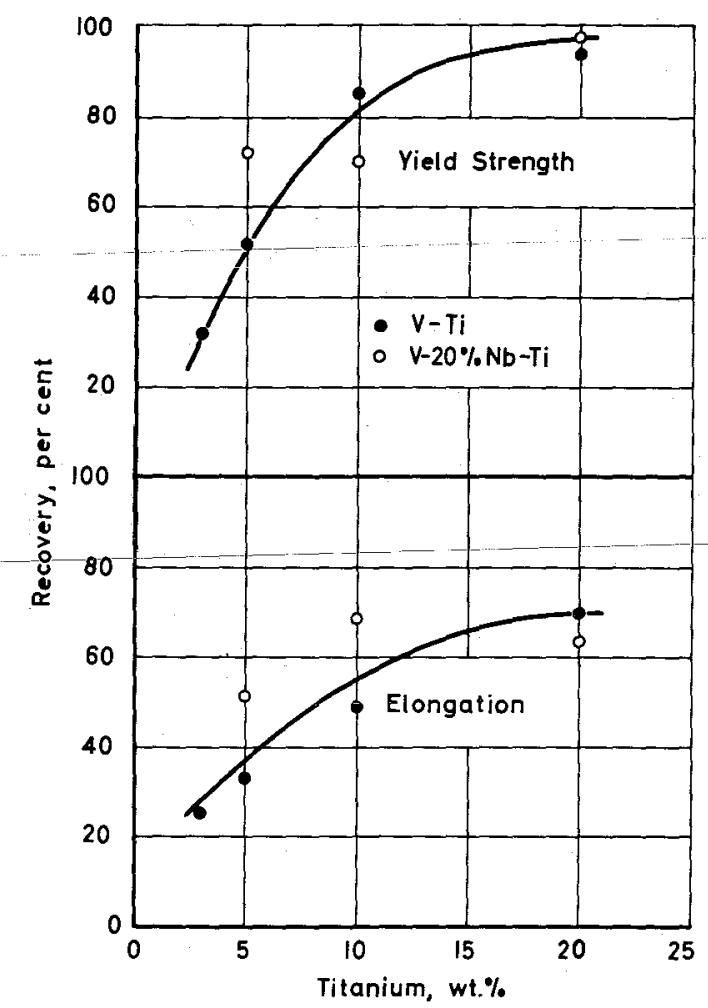

FIG. 2-Recovery of the yield strength and elongation of irradiated vanadium alloys after annealing $(5 \mathrm{hr} 600 \mathrm{C})$.

\section{Experimental Results}

At room temperature, all alloys show irradiation embrittlement to such an extent that yield strength and tensile strength in some cases nearly coincided and reduced total elongation to very low values (Table 1).

In Fig. $1 a$ the yield strength of the vanadium-titanium alloys before and after irradiation is shown as a function of the titanium content. Figure $1 b$ shows the corresponding data for the ternary V-Ti-Cb-alloys with a constant columbium content of 20 per cent. The parallel course of 
the two curves in Fig. 1 $a$, which both exhibit a strength minimum around 5 per cent titanium, shows that radiation damage in the binary $\mathrm{V}-\mathrm{Ti}$ alloys results in an absolute increase in yield strength by about $35 \mathrm{~kg} / \mathrm{mm}^{2}$, independent of the titanium content. In the ternary $\mathrm{V}-20 \mathrm{Cb}-$ $\mathrm{Ti}$ alloys (Fig. $1 b$ ), however, there is an influence of the titanium content on the increase in yield strength due to irradiation; there is a maximum of about $50 \mathrm{~kg} / \mathrm{mm}^{2}$ for 5 per cent titanium, decreasing with increasing titanium content until it reaches at 20 per cent titanium the value observed for the binary alloys, that is about $35 \mathrm{~kg} / \mathrm{mm}^{2}$. Other alloys, not included in the figures, show an increase in yield strength with absolute values in the same range (Table 1 ).

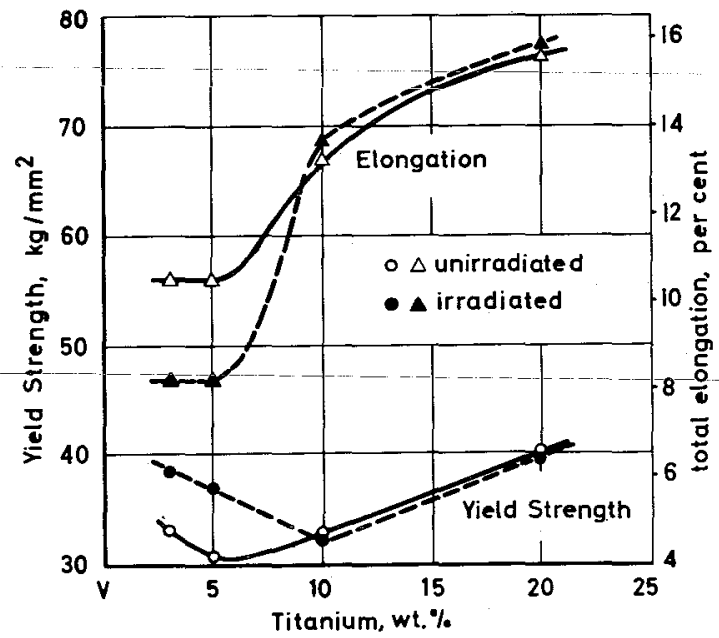

FIG. 3-Pre- and postirradiation yield strength and total elongation of vanadium alloys at $650 \mathrm{C}$.

For total elongation, it is not possible to determine a clear relationship of this type, which is undoubtedly due to scatter in the determination of very small elongations.

Figure 2 illustrates the radiation damage annealing process in which the recovery of the yield strength and ultimate elongation are shown as a function of the titanium content for the vanadium-titanium alloys and the vanadium-titanium-columbium alloys after $5 \mathrm{hr}$ of vacuum annealing at $600 \mathrm{C}$. It is clearly shown that the extent of recovery of the mechanical properties strongly increase with increasing titanium, not only in the binary, but also in the ternary vanadium-titanium-columbium alloys, that is, the titanium content has a remarkable influence upon the recovery processes. While the yield strength of alloys with 20 per cent titanium practically reaches the value for unirradiated specimens, this is not the case for elongation. Here; a relative decrease of about 30 
per cent remains unrecovered. It is not certain whether this residual damage is due to irradiation effects or whether a low oxygen uptake during annealing should be regarded as the cause. Experiments to learn the influence of annealing in air upon the mechanical properties showed a decrease in elongation without any change in yield or tensile strength, confirming this latter assumption.

A confirmation of the strong influence of the titanium content upon the annealing of radiation damage is given in Figs. 3 and 4. Figure 3

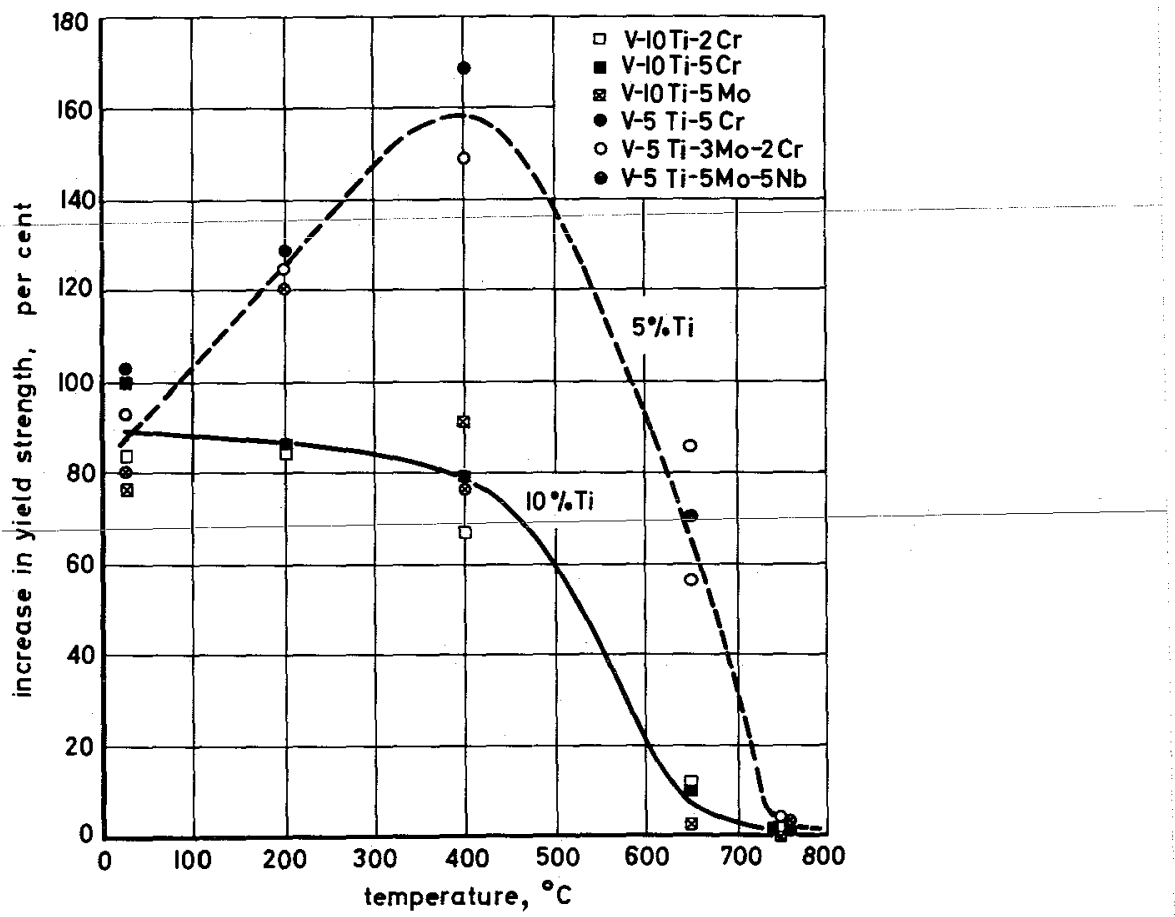

FIG. 4-Influence of test temperature on the increase in yield strength after irradiation at $\approx 100 \mathrm{C}$.

contains the values for the yield strength and total elongation of the binary vanadium-titanium alloys at $650 \mathrm{C}$ before and after irradiation. Before the tension test, the specimens in each case were kept at the temperature of test for $30 \mathrm{~min}$. From the figure it is obvious that at titanium contents $>10$ per cent there is already a complete recovery from the damage, whereas with lower titanium contents, the higher yield strengths and the lower elongations indicate incomplete recovery at 650 C. Exactly the same influence of the titanium content is found in the other alloys.

Figure 4 gives the values of the percentage increase in yield strength by irradiation as a function of the test temperature for all the ternary 
alloys tested at temperatures between room temperature and $750 \mathrm{C}$. The figure confirms that the radiation damage in alloys with 10 per cent titanium is annealed out at a temperature of $650 \mathrm{C}$, whereas a full annihilation of the radiation damage in alloys with 5 per cent titanium is obtained only at a temperature of $750 \mathrm{C}$. Furthermore, the figure shows an increase in $\Delta \sigma / \sigma_{s}$ at 200 and $400 \mathrm{C}$ for the alloys containing 5 per cent titanium, indicating that there is a smaller decrease in yield strength with temperature in the irradiated specimens than in the unirradiated specimens of these alloys.

The mechanical properties values at 650 and $750 \mathrm{C}$ show that, at these important temperatures for fuel element design, there will be no high temperature embrittlement for the specific experimental irradiation exposure. The increase in yield strength of the low titanium alloys at $650 \mathrm{C}$ clearly indicates that the embrittlement is due to point defects and is not of the "high-temperature-embrittlement" type.

\section{Discussion of the Results}

The high embrittlement due to irradiation of vanadium alloys at room temperature is in agreement with the known behavior of other body-centered cubic metals, such as molybdenum or columbium, which also exhibit very small elongations after irradiation to $10^{20} \mathrm{n} / \mathrm{cm}^{2}[3,4]$. In the case of molybdenum there is a distinct increase in the total elongation of irradiated specimens when the testing temperature is increased to $+80 \mathrm{C}$, that is, there is a transition from brittle to ductile behavior, in the tension test. The vanadium alloys do not show a similar behavior, indicated by the fact that elongation is not remarkably increased up to $400 \mathrm{C}$.

A very marked phenomenon in all alloys is the influence of the titanium content upon the recovery of the mechanical properties. The incomplete recovery at titanium contents of 3 and 5 per cent after annealing at $600 \mathrm{C}$, or during hot tension tests at $650 \mathrm{C}$ indicates definitely lower diffusion rates at these concentrations. This is in agreement with creep tests of unirradiated specimens in this temperature range. ${ }^{3}$ Thus, alloys with titanium contents around 5 per cent, despite lower hightemperature tensile strength than alloys of a higher titanium content, show a definitely lower creep rate at equal stress. The activation energy of creep and thus, most probably also of diffusion, increases very rapidly with increasing titanium content, that is, above a temperature of about 600 to $650 \mathrm{C}$, the diffusion in alloys with titanium contents 10 per cent becomes definitely greater than in alloys of lower titanium contents. In an analogous way, this holds for complex vanadium-titanium alloys also according to the results of the creep tests.

\footnotetext{
${ }^{3}$ Böhm, H. and Schirra, M., unpublished results.
} 
For the use of vanadium alloys as canning materials, the behavior at high temperatures is a decisive factor. At the test temperature of 650 and $750 \mathrm{C}$, none of the alloys showed signs of high-temperature embrittlement after irradiation. This may have two essential causes, namely:

1. The amount of helium formed by irradiation through $(n, \alpha)$-reactions may have been insufficient to cause embrittlement.

2. It is possible that vanadium alloys in principle show no hightemperature embrittlement, at least not in the temperature range investigated.

The helium content after irradiation is calculated from the thermal $\mathrm{B}^{10}(n, \alpha) \mathrm{Li}^{7}$ reaction and the $(n, \alpha)$-reaction of vanadium, titanium, and columbium with fast neutrons. A chemical analysis of the V-20Ti alloys showed a boron content of $2 \mathrm{ppm}$, corresponding to a helium concentration of about $10^{-6}$ atmos/atmos at the thermal neutron dose_of $1.2 \times 10^{21} \mathrm{n} / \mathrm{cm}^{2}$. An estimate of the helium formed after $1.4 \times 10^{21}$ $\mathrm{n} / \mathrm{cm}^{2}$, based on the fast $(n, \alpha)$-reactions with vanadium, titanium, and columbium, results in a value of $1.6 \times 10^{-7}$ for alloys with 20 per cent titanium. At these helium concentrations a distinct high-temperature embrittlement at temperatures above some 0.45 to $0.50 T_{M}$ can be observed in nickel alloys of comparable strength, and also in lower strength austenitic steels [5]. The test temperature of $750 \mathrm{C}$ in vanadium alloys having titanium contents above 10 per cent corresponds to an homologous temperature of about $0.47 T_{M}$ and, as is borne out by the recovery tests at $600 \mathrm{C}$ as well as the creep tests, is in the range of marked diffusion.

For the interpretation of the behavior at these temperatures, the irradiation temperature must be taken into consideration. There are some results [6] which show that there is an influence of the irradiation temperature on the degree of high-temperature embrittlement, but no result is known which indicates a high-temperature embrittlement only after high-temperature irradiation, and which cannot be reproduced by high-temperature postirradiation testing or annealing in the absence of prior irradiation at high temperature. Therefore, it is probable that the vanadium alloys will not show a high-temperature embrittlement even after irradiation at elevated temperatures at the same dose.

The complete absence of high-temperature embrittlement in these alloys at 650 and $750 \mathrm{C}$ thus cannot be due to an insufficient helium content or a too low diffusion rate. Instead it is necessary also to consider the fracture mechanism, which is strongly related to the hightemperature embrittlement behavior. This embrittlement will be more marked in a material which is inclined to show intercrystalline fracture in the unirradiated state. Under this assumption, which can be deduced from the mechanism of embrittlement, it is possible also to explain the 
behavior of the vanadium alloys. The metallographic investigation of hot tension and creep test specimens, as is shown in Fig. 5, indicates that vanadium alloys, even at a temperature of $950 \mathrm{C}$, still show transcrystalline fracture. Hence, it may be expected that the vanadium alloys, even at temperatures above $750 \mathrm{C}$, will not exhibit a marked tendency towards high-temperature embrittlement.

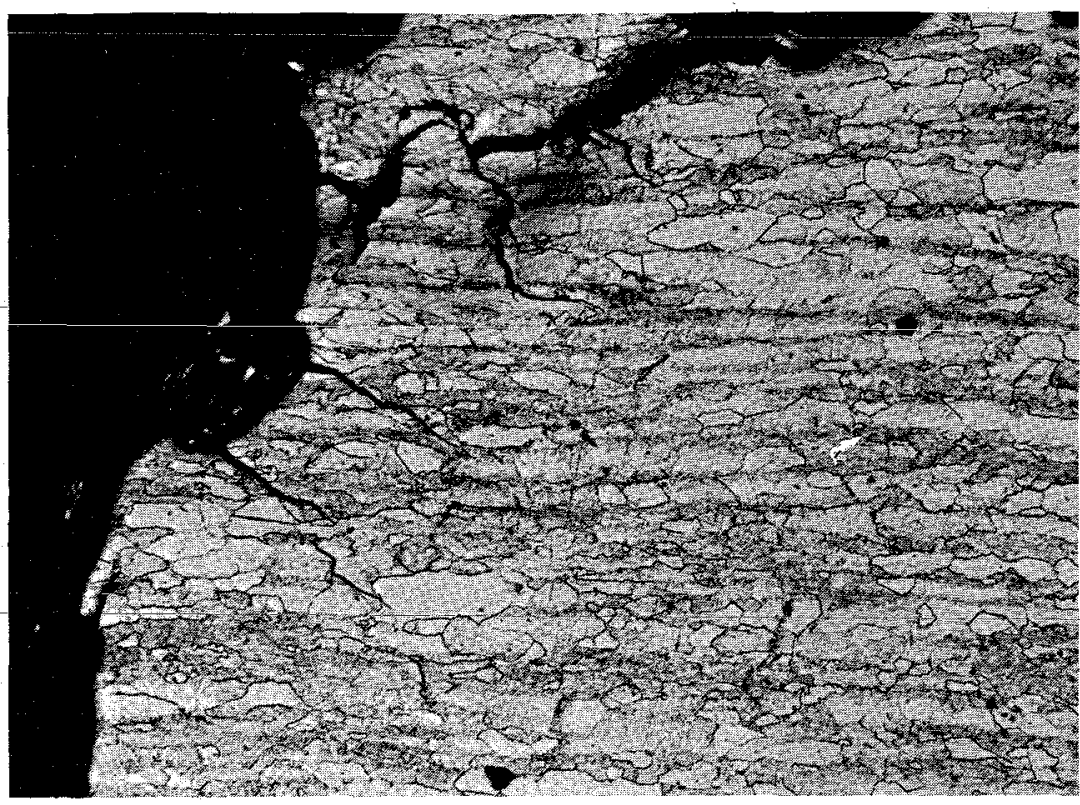

FIG. 5-Transcrystalline fracture in $V-5 T i-20 C b$ tension test at $950 C(\times 150)$.

\section{Summary}

Experiments were carried out to establish the influence of neutron irradiation $\left(1.4 \times 10^{21} \mathrm{n} / \mathrm{cm}^{2}, E>100 \mathrm{kev}\right)$ on the mechanical properties between room temperature and $750 \mathrm{C}$ of different vanadium base alloys. The increase in the absolute values of the yield strength in the binaryvanadium-titanium alloys due to irradiation is independent of titanium content. On the other hand, in the vanadium-titanium-columbium alloys with a constant columbium content of 20 per cent, the degree of increase in the yield strength falls with increasing titanium content.

At the test temperature of $650 \mathrm{C}$, it was observed that in the binary vanadium-titanium alloys, as well as in the ternary vanadium alloys containing titanium, there was a complete recovery of the irradiation damage at titanium contents of 10 per cent or more, while at lower titanium contents there was still a clear indication of unrecovered radiation damage. The strong influence of titanium on the annealing of radiation dam- 
age was determined experimentally by means of irradiated specimens whose mechanical properties were determined at room temperature after a 5 -hr anneal at $600 \mathrm{C}$.

At 650 and $750 \mathrm{C}$, and at the above mentioned irradiation dose, the vanadium alloys show no indication of high-temperature embrittlement.

\section{References}

[1] Smith, K. F. "Development of Vanadium Alloys for Reactor Application. Part I. Evaluation," Reactive Metals, Clough, W. R., ed., Interscience, New York/ London, 1959, p. 403.

[2] Van Thyne, R. J. "Development of Vanadium Alloys for Reactor Application. Part II. Mechanical Properties," Reactive Metals, Clough, W. R., ed. Interscience, New York/London, 1959, p. 415.

[3] Bruch, C. A., Hugh, W. E., and Hockenbury, R. W., "Embrittlement of Molybdenum by Neutron Radiation," Transactions, American Institute of Mining, Metallurgical, and_Petroleum Engineers, Vol. 203,-1955, p. 281-

[4] Makin, M. J. and Minter, F. J., "The Mechanical Properties of Irradiation Niobium," Acta Metallurgica, Vol 7, 1959, p. 361.

[5] Harries, D. R., "Neutron Irradiation Embrittlement of Atustenitic Stainless Steels and Nickel Base Alloys," Journal, British Nuclear Energy Society, Vol 5, 1966, p. 74 .

[6] Martin, W. R. and Weir, J. R., "Effect of Irradiation Temperature on the Postirradiation Stress-Strain Behaviour of Stainless Steels," ORNL-TM-906, Oak Ridge National Laboratory, 1964.

\section{DISCUSSION}

Mikael Grounes ${ }^{1}$ (written discussion)-In connection with calculations on transmutation problems in structural materials in fast reactors, we have noted that a quite high vanadium burn-up can be obtained due to a $(n, \gamma)$ reaction with thermal neutrons, for example 4.4 per cent burnup after $10^{22} \mathrm{n} / \mathrm{cm}^{2}$. Can this transformation of vanadium into chromium have any influence on the properties of vanadium alloys in the applications you have in mind?

H. Böhm (author) - It is to be expected that a transmutation of vanadium into chromium will have an influence on the properties of the alloys, but we think that there is no detrimental effect, because chromium is used as an alloying element for vanadium alloys in the mentioned concentrations to increase the corrosion resistance.

T. T. Claudson, ${ }^{2}$ (written discussion)--In your investigations of several vanadium alloys, have you made tentative selections as to particular

\footnotetext{
${ }^{1}$ Head, Structural Materials Laboratory, A B Atomenergi, Studsvik, Nyköping, Sweden.

${ }^{2}$ Manager, Mechanical Metallurgy, Battelle-Northwest, Richland, Wash.
} 
alloys for your applications in terms of irradiation damage and corrosion resistance in sodium environments?

Dr. Böhm-It is very difficult to make a selection at this early stage of investigation. For applications at 600 to $650 \mathrm{C}$ a higher titanium content would be desirable with regard to the radiation damage and corrosion resistance. On the other hand, the low titanium-containing alloys show much better creep-rupture properties than alloys with a titanium content above 10 per cent. We think the main problem now for an application of vanadium-base alloys is the corrosion resistance, and only after a thorough investigation of the corrosion behavior will it be possible to make a real selection.

S. B. McRickard ${ }^{3}$ (written discussion) - In view of your intended application of these alloys as structural materials in fast reactors, do you -plan any-elevated-temperature irradiation tests in sodium?

Dr. Böhm-Yes, we do plan irradiation experiments with vanadiumbase alloys in sodium at elevated temperatures.

${ }^{3}$ Metallurgy associate, Brookhaven National Laboratory, Upton, N. Y. 